\title{
F211
}

\section{夏季屋外歩行時の暑熱負担の挙動と 空気循環型防暑服着用による軽減効果}

\author{
澤田 晋一 ${ }^{1}$ 、岡 龍雄 ${ }^{1}$ 、福田 秀樹 ${ }^{1}$ 、久永 直見 ${ }^{1}$ \\ 独立行政法人 産業医学総合研究所
}

【はじめに】近年夏季の屋外建設業を中心として熱中症による労働災害が多発しており、厚生労働省は第 10 次労働災害防止計画の中で熱中症の適切な予防対策の徹底を図るとしている。従来から国内外で熱中症予防 のための暑熱許容基準が提案されているが、WBGT(湿球黒球温度指数)を用いたその基準值と暑熱負担との 関連は必ずしも明確でない。一方、暑熱ストレスを軽減するために種々の防暑服が開発され市販されている が、それらの有効性を労働生理・温熱生理学的見地から詳細に評価する必要がある。本研究の目的は、第一 に夏季屋外暑熱環境下での歩行時の暑熱負担の挙動を暑熱許容基準(WBGT)との関連で調べること、第二に その際の暑熱負担が空気循環型防暑服(以下空調服と略称)着用によりどの程度生理的・心理的に軽減される かその有効性を検討すること、以上の 2 点である。

【対象と方法】健康な成人男子 8 名(22〜24 歳)を対象として、7月に産業医学総合研究所のテニスコートで炎 天下歩行実験を行った。被験者は、保温力 $0.5 \mathrm{clo} \sim 0.6 \mathrm{clo}$ の夏服を着用し、時速約 $5 \mathrm{~km}$ の平地歩行を 45 分間 行った。その際、被験者をランダムに 4 名ずつ 2 グループ(A,B)に分け、A グループに空調服を非着用、B グ ループに着用させ、13:25〜 14:10 の時間帯に歩行させた。約 1 時間休賏後、 A グループに空調服を着用、B グループに空調服を非着用として、15:10〜15:55 の時間帯に同様の歩行を行わせた。測定項目は、(1)温熱環 境条件 : 気温、湿度、風速、黒球温、WBGT、(2)生理的負担 : 体内温(舌下温)、体表面温(皮膚温 8 所)、心 拍数、体重減少率、(3)心理的負担 : 温熱的快不快感、温冷感、温熱的好み、温熱条件の受け入れ難さ、温熱 条件の耐え難さ、のどの渴き感、および熱中症関連諸症状(めまい、はきけ、腹痛、耳鳿、步行困難、四肢感 覚異常など)であった。

【結果】(1)屋外暑熱条件 : 実験時(13:00 16:00)の天候は快晴かつ有風であり、屋外温熱環境条件は、気温 :

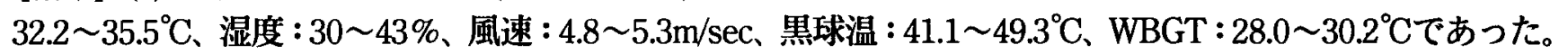
(2)生理的暑熱負担 : 舌下温は歩行中徐々に上昇し最終値(平均士標準偏差[最小值〜最大值])は、空調服非着用 群( $\mathrm{N}$ 群)で $36.86 \pm 0.44^{\circ} \mathrm{C}\left[36.39 \sim 37.51^{\circ} \mathrm{C}\right]$ 、着用群( $\mathrm{C}$ 群)で $36.98 \pm 0.48^{\circ} \mathrm{C}\left[36.31 \sim 37.74^{\circ} \mathrm{C}\right]$ となった。体重減少 率は、 $\mathrm{N}$ 群 : $0.66 \pm 0.09 \%[0.53 \sim 0.82 \%] 、 \mathrm{C}$ 群 : $0.72 \pm 0.28 \%[0.53 \sim 1.37 \%]$ 、平均心拍数は、 $\mathrm{N}$ 群 : 95.5 $\pm 10.6 \mathrm{bpm}[85.7 \sim 111.4 \mathrm{bpm}] 、 \mathrm{C}$ 群 : 95.7 $12.7 \mathrm{bpm}[78.4 \sim 118.3 \mathrm{bpm}]$ であった。部位別皮膚温の平均值は、 足背が最高値 $\left(\mathrm{N}\right.$ 群 : $36.8 \pm 0.38^{\circ} \mathrm{C} 、 \mathrm{C}$ 群 : $36.9 \pm 0.33^{\circ} \mathrm{C}$ )を示し、空調服着用時に空調ファンの近傍の腰部で最 低値を示した $\left(\mathrm{N}\right.$ 群 : $35.1 \pm 1.08^{\circ} \mathrm{C} 、 \mathrm{C}$ 群 : $\left.33.9 \pm 1.85^{\circ} \mathrm{C}\right)$ 。ただし、以上のすべての生理的測定項目で、 $\mathrm{N}$ 群と C群の間で有意差は認められなかった。(3)心理的暑熱負担 : 不快感、温冷感、汗ばみ感などの主観申告值は 実験中に徐々に增加し、一部の申告でN群とC群の間に有意差がみられる時点もあったが、ほとんどすべて の申告值に両群間で有意差なく、熱中症の関連症状の発現もほとんど見られなかった。

【考察と結論】(1)ISO7243 によれば今回の実験の代謝率区分は中程度代謝率 $(5 \mathrm{~km} / \mathrm{h}$ の平地歩行）に相当し、 その場合の WBGT 基準値は暑熱順化者で $28^{\circ} \mathrm{C}$ 、暑熱非順化者で $26^{\circ} \mathrm{C}$ なる。実験時の温熱条件はこの基準 をやや超えていたが、被験者の生理的・心理的負担の水準は、すべて安全圈内であった。これは ISO の現行 基準値の安全係数が十分高いことを示唆する。(2)今回のような晴天・有風下の屋外気象条件下での歩行によ り生ずる暑熱負担に対しては空調服の着用は著明な軽隇効果をもたらさなかった。空調服の着用が効果を発 揮する暑熱条件を明らかにするために、今後も様々な屋内・屋外気象条件下(無風で静的筋労作等で着用実 験を進める必要がある。 